\title{
Lattice-like paraproteinemic keratopathy (PPK) of monoclonal gammopathy of undetermined significance (MGUS)
}

\author{
Ivo Gama, Leonor Almeida
}

Department of Ophthalmology, University Hospital Santa Maria, North Lisbon Hospital Center, University of Lisbon, Medical Faculty of Lisbon, Lisbon, Portugal

\section{Correspondence to} Ivo Filipe Gama, ivogama20@hotmail.com

Accepted 14 January 2017
CrossMark

To cite: Gama I, Almeida L. BMJ Case Rep Published online: [please include Day Month Year] doi:10.1136/ bcr-2016-218031

\section{DESCRIPTION}

A male patient aged 71 years presented with a history of progressive visual loss in the past 3 years. Ophthalmological evaluation showed a bestcorrected visual acuity of 20/200 bilaterally and the presence of bilateral linear lattice-like corneal opacities similar to lattice dystrophy (LD) and dense nuclear cataracts at slit lamp examination (figure 1). There was no family history of ocular diseases. Serum protein electrophoresis included in the systemic investigation showed a band in the $\gamma$-globulin fraction (figure 2). Nephelometry detected an increased level of $\kappa$ light chains $-75.6 \mathrm{mg} / \mathrm{dL}$ (normal: $3.3-19.4 \mathrm{mg} / \mathrm{dL}$ ) and a normal level of $\lambda$ light chains-14.4 mg/dL (normal: $5.7-26.3 \mathrm{mg} / \mathrm{dL}$ ) and an increased $\kappa / \lambda$ ratio of 5.25 (normal: 0.261.65). Immunoelectrophoresis also confirmed the IgG-K gammopathy. Myelogram showed 2\% of plasma cells. No lytic bone lesions were present on plain X-ray. No mutations were found on transforming growth factor $\beta$-induced gene (TGFBI) nor on gelsolin gene sequencing. The diagnosis of lattice-like paraproteinemic keratopathy (PPK) secondary to monoclonal gammopathy of unknown significance (MGUS) was made. The patient was subsequently followed-up in Haematology. Cataract surgery followed by corneal transplant was proposed.

MGUS-induced PPK is rare and is caused by corneal immunoglobulin deposition. ${ }^{1}{ }^{2}$ Lattice-like PPK secondary to MGUS is even rarer and only eight cases have been reported. ${ }^{23}$ PPK can simulate LD. ${ }^{23}$ The abnormalities on SEP and subsequent investigations lead to the MGUS diagnosis. The negative family history and the absence of TGFBI/gelsolin mutations excluded LD and Meretoja syndrome. The late-onset lattice-like corneal pathology, without family history nor TGFBI/gelsolin gene mutations should raise the suspicion of PPK leading to the necessary clinical and laboratorial investigations. ${ }^{2}$

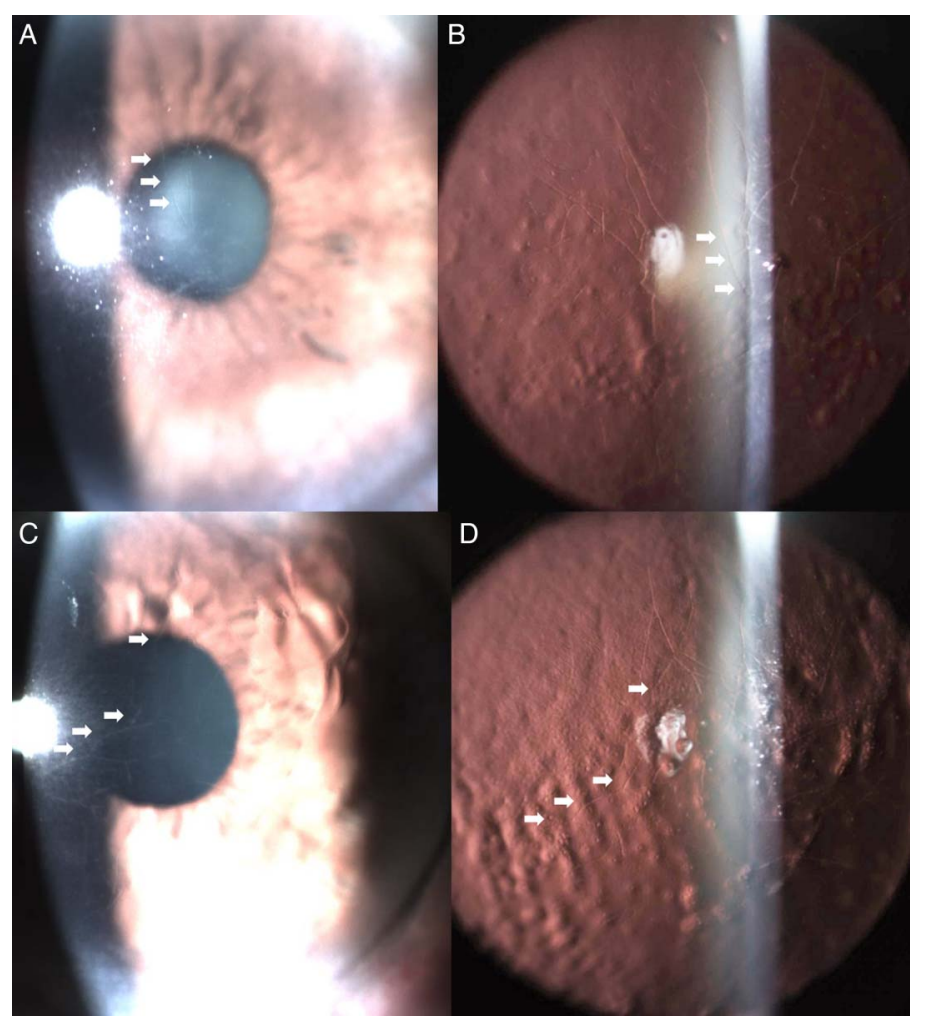

Figure 1 Slit lamp photography of anterior segment of the right eye under diffuse illumination (A) and retro-illumination techniques (B), showing linear lattice-like corneal opacities (white arrows). The slit lamp photography of the left eye under the same illumination techniques ( $C$ and $D$, respectively) also shows the presence of a lattice-like corneal phenotypic appearance of the fellow eye simulating lattice dystrophy (white arrows). 


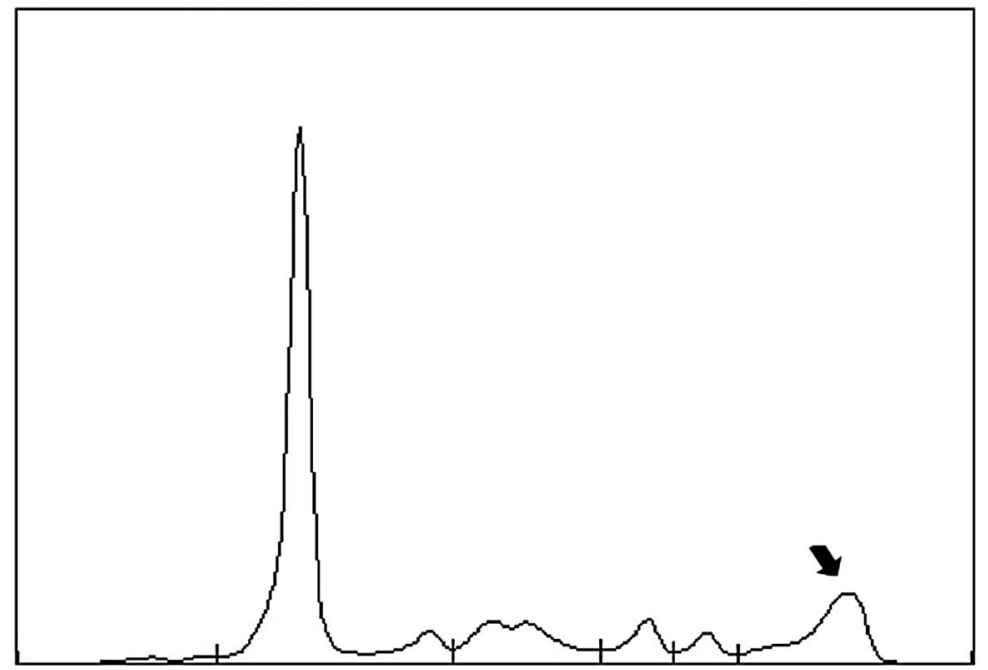

Figure 2 Serum protein electrophoresis showed a band in the $\gamma$-globulin fraction with a spike of $0.4 \mathrm{~g} / \mathrm{dL}$ (black arrow).

\section{Learning points}

- Paraproteinemic keratopathy (PPK) is rare, but when occurs is usually associated with plasma cell dyscrasias and is caused by corneal immunoglobulin deposition.

- Lattice-like PPK is a rare type of PPK. Only very few cases have been previously described with lattice-like PPK. ${ }^{2}$

- As lattice dystrophy (LD) and Meretoja syndrome (MS) have an autosomal-dominant pattern of inheritance, the possibility of PPK should be considered in a patient with late-onset of bilateral linear lattice-like corneal opacities in the absence of a family history of similar corneal pathology and a serum protein electrophoresis should be performed. The absence of TGFBI and gelsolin mutations ruled out LD and MS. The bilateral lattice-like corneal phenotypic appearance in the absence of family history and TGFBI/ gelsolin mutations may be caused by PPK.
Contributors IG and LA participated in patient care. IG was responsible for the review of clinical records and slit lamp photographs. IG was responsible for manuscript drafting and LA reviewed the manuscript and approved the final corrected version to be submitted for publication.

Competing interests None declared.

Patient consent Obtained.

Provenance and peer review Not commissioned; externally peer reviewed.

\section{REFERENCES}

1 Milman T, Kao AA, Chu D, et al. Paraproteinemic keratopathy: the expanding diversity of clinical and pathological manifestations. Ophthalmology 2015; 122:1748-56.

2 Lisch W, Wasielica-Poslednik J, Kivelä T, et al. The hematologic definition of monoclonal gammopathy of undetermined significance in relation to paraproteinemic keratopathy (An American Ophthalmological Society Thesis). Trans Am Ophthalmol Soc 2016:114:T7.

3 Kamal KM, Rayner SA, Chen MC, et al. Classic lattice corneal dystrophy associated with monoclonal gammopathy after exclusion of a TGFBI mutation. Cornea 2009;28:97-8.

Copyright 2017 BMJ Publishing Group. All rights reserved. For permission to reuse any of this content visit http://group.bmj.com/group/rights-licensing/permissions.

BMJ Case Report Fellows may re-use this article for personal use and teaching without any further permission.

Become a Fellow of BMJ Case Reports today and you can:

- Submit as many cases as you like

- Enjoy fast sympathetic peer review and rapid publication of accepted articles

- Access all the published articles

- Re-use any of the published material for personal use and teaching without further permission

For information on Institutional Fellowships contact consortiasales@bmjgroup.com

Visit casereports.bmj.com for more articles like this and to become a Fellow 